\title{
TRANSKRIP WAWANCARA
}

\section{Siswa RA B}

\section{Februari 2017}

\author{
Peneliti : Adik namanya siapa? \\ Peserta didik : Emma \\ Peneliti : Emma rumahnya di mana? Jauh nggak? \\ Peserta didik : Eeeee.....nggak, di sini kok rumahku. \\ Peneliti : Di sini. Seneng nggak main sama teman-temannya? \\ Peserta didik : Seneng. \\ Peneliti : Emma sudah berapa tahun di Tiara Chandra. \\ Peserta didik : Aaaaaa.....belum lama. Dulunya waktu aku kecil di TK ABA. \\ Peneliti : Ooooh. Di sini TK A dulu atau TK B langsung? \\ Peserta didik : Aaaaa.....TK A sama TK B. \\ Peneliti : Berarti 2 tahun ya. \\ Peneliti : Seneng main sama teman-teman ya? \\ Peserta didik : Seneng. \\ Peneliti : Kalau sama teman-teman, main bareng apa nggak? \\ Peserta didik : Bareng. \\ Peneliti : Kalau ada teman yang butuh bantuan, Emma suka bantu apa nggak? \\ Peserta didik : Suka, iya aku mau belajar. \\ Peneliti : Kenapa temannya dibantu. \\ Peserta didik : Yo biar.....biar nggak apa-apa. \\ Peneliti : Kalau menemunkan punya teman, dikembalikan atau nggak? \\ Peserta didik : Dikembalikan. \\ Peneliti : Kenapa diktembalikan? \\ Peserta didik : Nggak tau eeee.... \\ Peneliti : Terima kasih Emma.
}




\section{Februari 2017}

Peneliti : Mbak Ara kalau sama teman-teman suka main bareng nggak?

Peserta didik : Suka main bareng.

Peneliti : Suka main bareng?

Peserta didik : Ho'o

Peneliti : Kalau sama teman harus berbuat baik apa tidak?

Peserta didik : Berbuat baik.

Peneliti : Misalkan ada teman yang kesusahan, ada teman yang minta tolong, mbak Ara harus ditolong apa nggak?

Peserta didik : Menolong.

Peneliti : Menolong?

Peserta didik : Hu'um

Peneliti : Kalau misalkan mbak Ara ngeliat ada barang teman ketinggalan di kelas diapain?

Peserta didik : Aku ambil, langsung keluar, langsung buka tasnya, taruh tas, trus tutup langsung.

Peneliti : Dibalikin ke teman ya?

Peserta didik : Iya.

Peneliti : Terima kasih mbak Ara.

Peserta didik : Sama-sama.

Peneliti : Kalau sama umi-uminya disayangi nggak?

Peserta didik : Sayang.

Peneliti : Sayang banget nggak?

Peserta didik : Ho'o.

Peneliti : Kalau di rumah, sama saudara, mama, Bapak, sayang juga nggak? 
Peserta didik : Sayang.

Peneliti : Mbak Ara sudah berapa tahun di sini?

Peserta didik : Enam tahun. Bentar lagi tujuh tahun sudah mau masuk SD.

Peneliti : Mbak Ara seneng nggak di sini?

Peserta didik : Seneng.

Peneliti : Banyak teman nggak?

Peserta didik : Banyak.

Peneliti : Umi-uminya baik nggak sama Ara?

Peserta didik : Baik.

Peneliti : Ara pinter ya.

Peneliti : Kalau Ara berbuat salah, minta maaf nggak sih sama teman.

Peserta didik : Minta maaf.

Peneliti : Ya udah, terima kasih mbak Ara.

Peserta didik : Sama-sama.

\section{Februari 2017}

Peneliti : Namanya siapa dek?

Peserta didik : mmmmmmm....Jadid.

Peneliti : Jadid kelas berapa? RA apa?

Peserta didik : RA B1

Peneliti : Sudah berapa tahun di sini?

Peserta didik : Seribu...seribu kali.

Peneliti : Sudah berapa tahun kok seribu...seribu kali.

Peserta didik : 8 bulan.

Peneliti : 8 bulan? Trus dulu di mana sekolahnya?

Peserta didik : Di sini.

Peneliti : Senang nggak sekolah di sini?

Peserta didik : Senang. 
Peneliti : Banyak temannya nggak?

Peserta didik : Banyak.

Peneliti : Kalau sama teman-teman biasanya suka main bareng nggak?

Peserta didik : He'em. Tapi temannya nggak ada yang mau teman sama aku.

Peneliti : Kenapa?

Peserta didik : Soalnya teman-temanku itu suka marah-marah.

Peneliti : Suka marah-marah? Siapa itu yang marah-marah? Marahnya kenapa?

Peserta didik : Marah. Sukanya marah.

Peneliti : Kemarin itu kakak lihat kamu main kok sama teman-teman.

Peserta didik : Itu yang pas itu. sekarang sudah nggak punya teman. Bumi soalnya marah-marah sama aku.

Peneliti : Tapi siapa yang salah?

Peserta didik : Bumi. Bumi.

Peneliti : Salahnya apa? Yang gangguin dia atau Jadid?

Peserta didik : Dia.

Peneliti : Dia sudah minta maaf belum?

Peserta didik : Sudah.

Peneliti : Sudah minta maaf kok nggak dimaafkan?

Peserta didik : Dimaafkan.

Peneliti : Sekarang sudah baikan lagi?

Peserta didik : Sudah.

Peneliti : Kalau sama teman-teman harus main bareng ya.

Peserta didik : Iya.

Peneliti : Berarti sekarang sudah nggak sendiri lagi?

Peserta didik : Ho'o

Peneliti : Terus kalau Jadid lihat barang teman-teman berserakan atau ketinggalan diapain?

Peserta didik : Dibersihkan.

Peneliti : Trus ditaruh di mana barangnya? 
Peserta didik : Dibalikin di setra.

Peneliti : Trus dibalikin ke teman-temannya nggak?

Peserta didik : Bermain bareng-bareng.

Peneliti : Jadid suka berkata jujur nggak kalo ditanyain sama umi-nya?

Peserta didik : Jujur.

Peneliti : Boleh nggak berbohong?

Peserta didik : Nggak boleh.

Peneliti : Sama teman-teman suka kerja sama-sama, main bareng, gitu ya?

Atau suka main sendiri aja?

Peserta didik : Iya. Nggak main sendiri tu.

Peneliti : Ini teman-temannya Jadid, bukan?

Peserta didik : Iya.

Peneliti : Mereka baik nggak?

Peserta didik : Baik.

Peneliti : Jadid juga baik nggak?

Peserta didik : Baik.

Peneliti : : Terima kasih mas Jadid.

\section{Februari 2017}

Peneliti : Halo Jadid.

Peserta didik : Halo.

Peneliti : Kamu sayang nggak sama teman-temannya?

Peserta didik : Sayang.

Peneliti : Cara menyayangi teman kaya gimana?

Peserta didik : Tidak tau.

Peneliti : Ya mungkin dengan cara membagi makanan, dengan cara tidak mengganggunya, atau kaya gimana?

Peserta didik : Memberi makanan. 
Peneliti : Kalau Jadid bawa makanan dari rumah dikasi temannya nggak?

Peserta didik : Kasi. Tapi aku nggak bawa jajan.

Peneliti : Nggak bawa jajan? Kenapa nggak bawa?

Peserta didik : Besok aku bawa jajan tak kasi ke kamu (Temannya nyahut)

Peneliti : Siapa namanya ini?

Peserta didik : Syifa.

Peneliti : Syifa kalau bawa jajan suka kasi teman nggak?

Peserta didik : Ho’o, Suka.

Peneliti : Biasanya bawa jajan apa dari rumah?

Peserta didik : Cococran sama tango, sama yupi.

Peneliti : Trus biasanya kalo ngelihat ada sampah, ditaruh di mana sampahnya?

Peserta didik : Di tong sampah.

Peneliti : Bukan dilempar-lempar ke temannya ya?

Peserta didik : Bukan. Jijik i. Nggak boleh. Nggak sopan.

Peneliti : Kalau misalkan selesai bermain, mainannya itu dilempar-lempar atau ditaruh lagi?

Peserta didik : Taruh lagi.

Peneliti : Ditaruh lagi tunggu diperintah sama umi apa nggak?

Peserta didik : Diperintah sama umi.

Peneliti : Kalau uminya nggak perintah, nggak taruh?

Peserta didik : Hhhhhhmmmmmm....ditaruh.

Peserta didik : Aku pernah punya mainan, temanku mau minjem, aku pinjemin. (Syifa)

Peneliti : Oh kalau temanmu mau pinjem mainan, dipinjemin?

Peserta didik : Hu'um.

Peserta didik : Aku juga kalungnya juga dipinjemin. (Zizi)

Peneliti : Kamu seneng nggak main sama teman-teman?

Peserta didik : Suka. (sambil tertawa) 
Peneliti : Trus kalau kalian berbuat salah, ganggu teman, ada temannya yang dibuat nangis, minta maaf nggak?

Peserta didik : Minta maaf.

Peneliti : Habis minta maaf, main bareng lagi nggak?

Peserta didik : Main bareng lagi.

Peneliti : Senang ya main bareng sama teman?

Peserta didikt : Senang.

Peneliti : Terima kasih Jadid, Terima Kasih Syifa, Terima kasih Zizi.

\section{ORANG TUA PESERTA DIDIK Ibu Yanti (Orang tua dari Hasna RA B)} 28 Februari 2017

Peneliti : Assalamu'alaikum Ibu. Nama saya Amar. Saya mahasiswa S2 PGRA di UIN Sunan Kalijaga. Sekarang sedang melakukan penelitian dan butuh informasi dari wali murid, termasuk ibu. Penelitian saya ini tentang "Penanaman nilai-nilai karakter pada anak usia dini dengan pendekatan LVE”. Mohon maaf dengan Ibu siapa niki?

Bu Yanti : Yanti.

Peneliti : Oh nggih. Anak Ibu namanya siapa?

Bu Yanti : Hasna.

Peneliti : Oh Hasna. Saya sering main tu kalo lagi observasi tu. Hasna baik.

Peneliti : Hasna sudah lama di sini bu?

Bu Yanti : Dari play group dia.

Peneliti : Oh dari play group ya.

Peneliti : Jadi, ada beberapa hal yang ingin saya ketahui dari penanaman nilainilai karakter, nilai-nilai yang berhubungan dengan hal-hal positif, nilai-nilai kebaikan kepada anak-anak. Saya ingin tau bagaimana 
programa sekolah untuk orang tua dan hubungan antara sekolah dengan orang tua.

Peneliti : Kalau menurut ibu sendiri, apa sih pendidikan karakter itu?

Bu Yanti : Membentuk kepribadian anak ya. Dari misalnya anak belum mandiri, nanti di sekolah diajarin lebih mandiri. Kalau misalkan di rumah masih malas belajar, di sekolah dimotivasi guru, di rumah jadi rajin belajar. Salah satunya seperti itu.

Peneliti : Menurut ibu sendiri, pendidikan karakter (membentuk anak jadi anak yang baik, berbakti pada orang tua, baik sama teman, baik sama guru, dan lingkungan masyarakat, penting nggak ya?

Bu Yanti : Penting. Sangat penting malah. Lebih baik karakternya baik, jadi hubungan sosialnya juga baik. Kepada keluarga, guru, dan temanteman juga baik. Nanti untuk kemampuan kognitif (baca tulis) itu bisa mengikuti. Teori kan itu ya. Jadi lebih baik pengembangan karakter dulu.

Peneliti : Kalau yang ibu amati/lihat selama ini, hal-hal apa saja yang dilakukan oleh pihak sekolah (guru, atau kepala sekolah) dalam menanamkan nilai-nilai karakter pada anak?

Bu Yanti : Dari hal-hal kecil aja, misalkan sehabis makan harus membuang sampah pada tempatnya. Bermain harus dibereskan lagi. Kerja sama. Trus rasa percaya diri. Contohnya anak saya dari play group sampe TK A itu masih ditunggui di dalam kelas. Gurunya memberi motivasi terus sampe anak itu percaya diri. Pendekatannya juga, sikap dari gurunya ramah, mendekati terus. Jadi anak saya sampe sekarang diajak pulang malah nggak mau. Betah di sekolah.

Peneliti : Kalau perubahan yang paling mencolok dari Hasna sejak dulu sampai sekarang itu apa ibu terkait dengan karakter dia?

Bu Yanti : Lebih mandiri, percaya diri, trus mau berbagi. 
Peneliti : Kalau di rumah dia seperti apa dengan orang tua, saudara, tetangga, teman-teman?

Bu Yanti : Kalau di rumah kan nggak pernah bergaul ke luar. Jadi di rumah, ya di rumah. Makanya dia dari kecil pemalu. Trus setelah sekolah lebih percaya diri. Kalau di rumah juga mau bantu pekerjaan orang tua. Misalkan bangun tidur mau membereskan tempat tidur, melipat selimut, bisa mandi sendiri. Udah lebih mandiri sih sekarang.

Peneliti : Kemudian saya ingin tau, program apa sih yang dilakukan oleh sekolah yang melibatkan orang tua terkait dengan penanaman karakter? Misalnya di sekolah mengajarkan anak-anak harus bisa menghargai sesama, bertanggung jawab, dll. apakah sekolah mengajak orang tua untuk ikut melakukan hal yang sama di rumah? Dan seperti apa contohnya?

Bu Yanti : Mungkin seperti kegiatan tahunan kaya flea market (pasar murah) itu kan orang tua terlibat. Jadi kita cari barang pantas pakai, nanti kita jual ke penduduk sekitar sini. Setiap kelas ada kelompok sendiri, itu kan mencerminkan kerja sama, gotong royong. Hasil penjualan kita serahkan ke sekolah untuk dikelola dan disumbangkan ke tempat lain lagi. Kemudian juga ada perayaan Idul Adha, nanti ada kita mengumpulkan materi, diwujudkan dalam bentuk binatang, dan kita sumbangkan ke penduduk sekitar juga.

Peneliti : Kegiatannya satu tahun sekali ya bu?

$\mathrm{Bu}$ Yanti : Iya.

Peneliti : Dan ibu tetap terlibat ya?

Bu Yanti : Kalau itu harus terlibat. Karena seperti pasar murah itu kan per kelas, mau nggak mau harus terlibat.

Peneliti : Berarti sekolah juga mengajak orang tua untuk berpartisipasi ya dalam menghidupkan nilai? 
Bu Yanti : Iya. Supaya balance lah antara pendidikan di rumah dan di sekolah. Guru-guru di sini juga cara memberitahu anak-anak juga bagus kalau ada yang kurang bener. Jadi anak mudah paham sih.

Peneliti : Di sini kan ada kegiatan-kegiatan pelatihan, seminar, atau parenting terkait dengan pendidikan karakter, jadi apa yang diajarkan di sekolah juga pengen disampaikan sama orang tua agar di rumah juga dilaksanakan. Ibu juga pernah ikut nggak?

Bu Yanti : Kalau parenting saya sesekali ikut karena jamnya juga susah, ada kesibukan lain.

Peneliti : Dalam kegiatan parenting apa saja yang disampaikan?

Bu Yanti : Ya itu, salah satunya kepala sekolah memotivasi kita untuk membentuk karakter anak. Tiap pertemuan beda-beda, salah satunya tentang karakter.

Peneliti : Kalau ibu lihat Hasna banyak perubahannya ya terkait dengan karakternya?

Bu Yanti : Iya mas, banyak.

Peneliti : Apa kesannya terhadap sekolah ini?

Bu Yanti : Kesannya, yaaa umi-uminya sangat bagus sih dalam mendidik anakanaknya. Kalau kemampuan teori, baca tulis, bisa hafal-hafal saya sih tidak begitu memperhatikan karena itu sejalan dengan kemampuan anak-anak, yang penting mereka pernah mendengar. Yang penting karakternya aja dan umi-uminya bisa diandalkan untuk membentuk karakter anak-anak.

Peneliti : Terima kasih nggih ibu atas waktunya.

Bu Yanti : Nggih mas, sama-sama. 


\section{GURU RA TIARA CHANDRA}

\section{Umi Dewi (guru sentra seni)}

\section{Maret 2017}

Peneliti : Teman penelitian saya ini tentang "penanaman nilai-nilai karakter pada anak dengan pendekatan LVE"

Peneliti : Saya berbicara dengan umi siapa niki?

Umi Dewi : Umi Dewi

Peneliti : Umi Dewi posisinya atau jabatannya di sini sebagai apa?

Umi Dewi : Guru sentra seni.

Peneliti : Saya ingin tau menurut umi apa sih pendidikan karakter itu?

Umi Dewi : Pendidikan karakter itu pendidikan yang melatih anak supaya anak itu terarah sesuai dengan usianya, bukan pendidikan yang menjerumuskan ke hal yang buruk.

Peneliti : Saya lihat di sekolah-sekolah kan lebih banyak yang mengutamakan kemampuan kognitif, tapi tidak banyak yang mementingkan karakter. Menurut umi apakah pendidikan karakter itu penting buat anak?

Umi Dewi : Kalau saya sebagai guru, saya lebih mementingkan pendidikan karakter ya pada anak. Kalau kita memforsir anak untuk bisa baca tulis, bisa ini itu, tidak baik ya. Harusnya kita mengajarkan nilainilai. Misalkan nilai-nilai agama dalam keluarga. Atau mungkin pendidikan yang mengajarkan anak sopan santun, hormat pada orang tua, masyarakat, teman, orang lain. Kalau kita melatih anak dari pendidikan karakternya dulu, insya Allah untuk perkembangan kognitif, Bahasa, dll bisa mengikuti. Lebih baik ke pendidikan karakternya dulu.

Peneliti : Konsep pendidikan karakter di sekolah ini apakah sudah dimuat dalam kurikulum, sudah ada di RPPH, rancangan kegiatan semester, dan di rapor? Apakah sudah dicantumkan nilai-nilai karakter? 
Umi Dewi : Sudah ada di sini. Misalkan di RPPH itu ada beberapa nilai karakter, seperti kerja sama, kasih sayang, saling menghormati itu di sekolah ini sudah tercantum dalam RPPH dan rapor.

Peneliti : Apakah dalam satu hari / minggu / bulan itu ada nilai-nilai karakter tertentu yang ditekankan?

Umi Dewi : Biasanya per tema. Misalnya bulan Januari kemarin tema Air atau Api nilai yang diajarkan kerjasama. Tema berikutnya Polisi atau Dokter, nilai yang diajarkan juga beda-beda dari yang kemarin.

Peneliti : Kalau di sentra umi sendiri bagaimana cara umi menanamkan nilainilai karakter itu?

Umi Dewi : Kalau di sentra saya sendiri biasanya melalui cerita. Misalnya tema polisi itu mau menanamkan nilai kasing sayang, kita menyayangi teman itu bagaimana sih. Saya biasanya mengadakan cerita terlebih dahulu, kasing sayang itu apa, tindakannya seperti apa, contohnya seperti apa.

Peneliti : Kalau umi sendiri mengenal LVE sejak kapan? Di sini sudah berapa lama sih umi ngajar?

Umi Dewi : Saya baru 1 tahun.

Peneliti : Udah pernah ikut pelatihannya pak Muqowim?

Umi Dewi : Belum pernah.

Peneliti : Kemarin nggak ikut ya umi?

Umi Dewi : Kemarin belum bisa ikut karena ada kegiatan lain.

Peneliti : Tapi tetap disampaikan sama umi yang lain ya?

Umi Dewi : Iya, tetap disampaikan.

Peneliti : Sejak umi di sini 1 tahun terakhir ini sudah berapa nilai yang ditanamkan ke anak-anak?

Umi Dewi : Kalau saya tiap anak beda-beda nilainya. Misalnya ada anak yang karakternya dia suka menyayangi teman, berarti setiap rapot saya 
mencatat nilai karakternya kasih sayang. Misalnya anak itu kurang sopan, berarti di rapotnya saya cantumkan nilai sopan santun.

Peneliti : Terkait dengan kerjasama antara guru dan orang tua. Kita ketika menginginkan anak menjadi A B atau C itu kan tidak bisa bekerja sendiri. Kita butuh peran orang tua juga karena kita sudah punya program yang bagus di sekolah, tanpa ada dukungan dari orang tua di rumah juga akan sulit. Bagaimana cara umi atau sekolah dalam bekerjasama dengan orang tua untuk mensukseskan penanaman nilainilai karakter pada anak?

Umi Dewi : Biasanya sih kalau saya sendiri waktu penerimaan rapot saya sosialisasi sama orang tua tentang karakter anak dulu. Ibu ini anaknya seperti ini, di sekolah seperti ini, kalau di rumah seperti apa ya Bu? Apakah sama dengan di sekolah? Biasanya kalau di sini seperti ini, tapi di rumah lain lagi, biasanya saya sampaikan ke wali murid untuk kerjasamanya untuk membimbing anak tersebut. Nanti ada face to face juga dan ada sharing juga.

Peneliti : Apakah ada evaluasi setelah itu? Mengkroscek apakah orang tua di rumah sudah mengikuti yang sudah umi sampaikan atau tidak. Anaknya sudah ada perubahan atau tidak.

Umi Dewi : Iya, biasanya sih seperti itu. Misalnya saya melakukan pengamatan, si anak kok belum ada perubahan ya, saya biasanya melakukan kroscek ke orang tuanya melalui telepon atau whatsapp, "Ibu ini si anak masih gini, kok belum ada perubahan, trus di rumah bagaimana? Mohon bimbingannya". Pasti ada evaluasi juga untuk perkembangan si anak.

Peneliti : Yang terakhir umi, dari semua anak itu kan tidak mungkin baik semua, bagus semua sesuai yang kita harapkan, ada saja kendala, ada saja anak-anak yang karakternya kurang baik. Menurut umi, kendala apa sih yang dihadapai? Apakah datang dari internal sekolah, 
mungkin guru yang belum mampu memberikan contoh yang baik, atau apakah datang dari keluarga dan lingkungan masyarakat?

Umi Dewi : Setiap anak pasti mempunyai kendala dan kendalanya pasti bedabeda. Antara anak yang satu dengan yang lain karakternya beda-beda. Mungkin itu juga biasanya kendalanya dari rumah. Anak kan terbiasa nurut sama gurunya, tapi di rumah didikan orang tua beda-beda. Dari sekolah sudah dibilangin, tapi di rumah tidak ada didikan orang tua, akhirnya di sekolah besoknya beda lagi. Sebagai guru kadang kurang tau seperti apa didikan dari orang tua di rumah.

Peneliti : Biasanya ada nggak program khusus mengunjungi rumah anak yang karakternya kurang baik?

Umi Dewi : Ada sih program khusus, tapi kendalanya susah bertemu sama orang tua karena walaupun sudah janjian ingin bertemu, tapi orang tua sering pulang sore atau ada kesibukan lainnya.

Peneliti : Terima kasih banyak njih umi.

\section{Umi Yani (guru sentra imtaq)}

\section{Februari 2017}

Peneliti : Assalamu'alaikum Umi.

Umi Yani : Wa'alaikumussalam Warahmatullah Wabarakatuh.

Peneliti : Ini saya ada beberapa pertanyaan yang terkait dengan penelitian saya tentang penanaman nilai-nilai karakter dengan pendekatan LVE. Saya butuh informasi dari umi yang sudah cukup lama di sekolah ini. Sudah berapa lama umi di RA Tiara Chandra?

Umi Yani : Sejak 2005 sampai sekarang. Berarti sekitar 12 tahun ya?

Peneliti : Sudah 12 tahun. Saya ingin tau umi, menurut umi sendiri apa sih pendidikan karakter itu? 
Umi Yani : Pendidikan yang tidak hanya mengajarkan pengetahuan kepada anak, tetapi juga di situ lebih menitikberatkan pada karakter atau kepribadian, sikap-sikap yang baik untuk anak.

Peneliti : Pendidikan karakter (kemandirian, berbuat baik, kehidupan sosial dengan orang lain, sayang teman, dll) menurut umi penting apa nggak sih? Atau biasa-biasa aja, atau lebih penting anak-anak diajarkan membaca dan menulis, kemampuan kognitif?

Umi Yani : Pada dasarnya pendidikan di TK sejak dulu itu tujuannya untuk mengangkat karakter, membentuk karakter anak sejak dini. Cuma, mungkin adanya pendidikan karakter itu beberapa waktu yang lalu aja diangkat menteri pendidikan yang menggaungkan adanya pendidikan karakter, tetapi pada dasarnya di kurikulumnya TK sejak awal itu sudah ada namanya penanaman karakter itu.

Peneliti : Berarti pendidikan karakter sangat penting ya umi.

Peneliti : Kalau konsep pendidikan karakter. Bagaimana sih rancangan pendidikan karakter di RA Tiara Chandra ini? Nilai-nilai karakter itu diajarkan seperti apa kepada anak-anak, kemudian mungkin dimasukkan dalam kurikulum, atau seperti apa umi?

Umi Yani : Seperti tadi saya bilang karena kemarin itu memang beberapa waktu yang lalu digaungkan pendidikan karakter sehingga di kurikulum terutama dimasukkan pendidikan karakter, dari berbagai macam karakter seperti tanggung jawab, jujur, disiplin, religious, dsb. itu sudah ada dalam kurikulum, kemudian untuk aplikasinya di KBM (kegiatan belajar mengajar) itu dijadikan pembiasaan sehari-hari. Tidak hanya sebatas teori, tetapi diajarkan secara praktek. Dan untuk di Tiara Chandra, untuk tahun ajaran ini memang difokuskan karakter itu satu bulan satu karakter. Misalnya kemarin bulan Januari kita mengajarkan karakter kasih sayang. Jadi ditanamkan kasih sayang itu seperti apa yang lebih dekat dengan mereka, misalkan kasih sayang 
kepada orang tua, teman-teman, tanaman dengan cara merawat, kasih sayang terhadap binatang dengan cara memberi makan binatang, seperti itu.

Peneliti : Jadi, guru-guru sendiri juga memberikan contoh secara langsung umi ya daripada hanya sekedar memberitahu bahwa kamu harus menyayangi ini harus menyayangi itu, tapi kegiatan KBMnya langsung dipraktekkan bagaimana menyayangi binatang, menyayangi tanaman, dsb.

Peneliti : Umi sendiri sejak kapan sih mengenal LVE?

Umi Yani : LVE memang saya tahun berapa ya? Mungkin sekitar 2010an ya. 2010an sudah ikut di pelatihan LVE-nya. Sebelum di Tiara Chandra karena waktu itu di Ikatan Guru Raudlatul Athfal (IGRA) Kota Jogja itu pernah mengadakan itu, dan yang mengisi pak Muqowim, kemudian baru setelah itu khusus untuk pendidik Tiara Chandra diadakan setiap tahunnya.

Peneliti : Setiap tahun selalu ada ya umi?

Umi Yani : Iya, selalu ada.

Peneliti : Berarti sejak itu sampai sekarang sudah berapa kali umi mengikuti pelatihan LVE?

Umi Yani : Ya sekitar 5 atau 6 kali lah.

Peneliti : Kalau menurut umi, apa sih yang membedakan LVE itu dengan pelatihan-pelatihan karakter yang lain? karena kadang kan dari kementerian juga sering mengadakan pelatihan pendidikan karakter ya.

Umi Yani : Mungkin bedanya kalau LVE itu tidak hanya mengajarkan karakterkarakternya, tetapi membangun, menghidupkannya dari diri kita. Jadi, kita tidak hanya tau, oh ini disiplin, oh ini jujur, tetapi kita sendiri itu dituntut untuk mulai disiplin, mulai jujur dari diri sendiri, 
tidak hanya sekedar untuk KBM di sekolah, tetapi untuk kehidupan kita pribadi juga.

Peneliti : Ada berapa jumlah nilai yang dihidupkan dalam satu tahun ajaran?

Umi Yani : Kalau kemarin kita coba sebulan satu karakter ya, berarti sekitar 10 (sepuluh) karakter. Dan juga dalam laporan perkembangan anak setiap semester kita beri di sana pesan-pesan nilai karakter yang harus dihidupkan khusus untuk anak itu, misalkan anak itu kok belum bisa tanggung jawab, berarti di sana kita beri pesan karakter "nilai tanggung jawab", seperti itu.

Peneliti : Masih ingat nggak umi ada nilai apa saja yang sudah dihidupkan kepada anak-anak dalam satu tahun ajaran?

Umi Yani : Kalau kemarin ada tanggung jawab, kasih sayang, cinta, menghargai, toleransi, jujur, damai, bahagia, kebersamaan, dll.

Peneliti : Ketika tidak semua anak bisa menghidupkan nilai-nilai itu, bagaimana cara guru meluruskan/mengingatkan kembali sesuai dengan nilai yang sudah disepakati/ditentukan?

Umi Yani : Yang pasti kita ingatkan lagi. Kan anak-anak di kelas tu diberi visual gambar-gambar tentang nilai karakter, gitu biasanya. Kalau dalam keseharian juga yang pasti kita kuatkan kembali dengan mengingatkan anak tentang nilai yang kita tanamkan di bulan itu.

Peneliti : Setelah beberapa tahun ini mengikuti pelatihan LVE kemudian menerapkannya dalam kegiatan sehari-hari di sekolah. Apa sih perubahan karakter yang dilihat antara yang dulu sebelum LVE dan sesudah LVE?

Umi Yani : Kalau perubahan karakter anak, gini mas, karena karakter anak ini terbentuknya tidak hanya di sekolah, jadi pendidikan, pembiasaan orang tua di rumah juga sangat kuat untuk itu. Saya kira sama-sama sih. Meskipun dulu kita belum menerapkan seperti ini, kalau memang anak itu dari rumah juga sudah diberi pendidikan karakter yang baik 
dari orang tua juga mereka bisa tanggung jawab, mereka bisa kerja keras, jujur gitu, berperilaku baik, menghargai. Kalau persentasenya saya kira sama-sama juga karena mungkin saat ini juga perubahannya belum begitu terlihat juga. Karena pengaruh orang tua di rumah itu sangat perlu. Karena kalau kita tanamkan hanya di sekolah saja mungkin ada anak yang masih belum tercapai karakter itu.

Peneliti : Terkait dengan hubungan antara sekolah dengan orang tua ni umi. Karena peran serta orang tua itu sangat penting untuk mensukseskan program sekolah. Apa sih program dari sekolah yang mengikutsertakan orang tua? Apa kegiatan sekolah yang harus diaplikasikan juga di rumah?

Umi Yani : Yang pasti di awal tahun ajaran kita beri kegiatan parenting untuk mensosialisasikan bahwa kita ada pendekatan/pendidikan karakter, dijelaskan seperti ini, seperti ini. Kemudian dua tahun terakhir ini memang ada perwakilan orang tua kita ikutkan pelatihan LVE. Cuma belum merata juga karena masih hanya perwakilan pengurus dan itu baru sekali-sekali, belum bisa menyambung lagi. Seperti kemarin yang baru ikut sekali, kemudian anaknya sudah lulus jadinya sudah nggak aktif lagi ke sini.

Peneliti : Ada nggak kegiatan misalkan di sekolah sekarang menanamkan nilai kejujuran. Tentu saja kita tidak bisa menuntut anak untuk berlaku jujur di sekolah saja, tapi juga di rumah perlu melakukan hal yang sama agar terus nyambung karena mereka menghabiskan waktu lebih banyak di rumah. Apakah umi-umi di sini punya program tertentu agar orang tua di rumah juga ikut menanamkan nilai yang sama dengan yang ditanamkan di sekolah?

Umi Yani : Kalau itu sementara belum ada. Sementara ini yang sudah berjalan baru materi hangout kemudian orang tua di rumah di kasi, kemudian diberitahu tema-temanya. Kalau untuk nilai memang belum kita 
sosialisasikan secara khusus bulan ini apa, temanya apa. Tapi untuk karakter anak, setiap ada kejadian atau kasus di sekolah tentang anak itu pasti kita sampaikan kepada orang tua ketika dijemput. Jadi misalkan tadi ini ada yang belum tanggung jawab merapikan mainan atau tadi sama temannya ada yang tangannya usil pasti akan kita sampaikan. Harapannya orang tua di rumah menindak lanjuti, supaya karakter anak terbentuk dengan baik.

Peneliti : Kalau umi sendiri pernah mengikuti pelatihan-pelatihan karakter selain LVE nggak?

Umi Yani : Ada. Satu kali dari IHF (Indonesia Heritage Foundation).

Peneliti : Bagaimana perbedaannya dengan LVE?

Umi Yani : Kalau IHF itu mereka sudah punya sekolah juga. Untuk usia PAUD mereka sudah mendirikan beberapa sekolah untuk contoh, kemudian udah punya program-program lebih rinci, jadi dari buku-buku, strategi untuk mengajarkan karakter ini, kemudian caranya dengan nyanyian, dengan dongeng, dengan buku cerita, lagu-lagu mereka sudah punya sudah ada iringannya istrumen seperti itu. Terus kemudian mereka sekolahnya itu dari TK, SD, SMP itu sudah punya. Jadi ketika dari TK nya sudah LVE, SD nya nyambung-nyambung sampe SMP.

Peneliti : Kalau kegiatan di luar sekolah ni umi, apa saja kegiatan-kegitan di luar sekolah untuk menghidupkan nilai-nilai karakter?

Umi Yani : Kita ada kegiatan penunjang yang utama, yaitu flea market atau semacam bakti sosial. Disitu memang melibatkan anak, orang tua untuk mengumpulkan sembako, kemudian barang bekas, pakaian pantas pakai, peralatan sekolah pantas pakai, mainan, kemudian kita datangkan beberapa warga sekitar untuk diberi sumbangan itu. Disitu kita memang mulai menghidupkan karakter ini dengan contoh misalkan dari setiap stand kelas itu nanti diberi nama karakter, 
misalnya yang di sini kebahagiaan, yang di sana stand kebersamaan, stand cinta, seperti itu. Harapannya itu orang tua juga lebih terlibat di situ, lebih bisa memahami artinya kebersamaan, cinta, seperti itu.

Peneliti : Terakhir terkait kendala-kendala. Apa saja sih kendala yang dihadapi oleh umi-umi atau sekolah terkait dengan penanaman nilai-nilai karakter pada anak? Karena kita kan tidak mungkin mengharapkan anak-anak semuanya langsung seperti yang kita mau. Mungkin ada faktor-faktor lain yang mempengaruhi, mungkin orang tua, keluarga, masyarakat, dll. Dari yang umi amati dari beberapa anak mungkin ada yang sudah bagus karakternya dan ada yang belum. Kalau yang belum itu sebenarnya masalah yang dihadapi apa sih?

Umi Yani : Yang pertama memang lingkungan rumah ya. Jadi penanaman karakter itu di lingkungan rumahnya oleh orang tuanya atau orang dewasa di sekitarnya ataupun juga mungkin dari lingkungan sekitar rumahnya yang biasa dia tonton, dia lihat di TV atau kalau zaman sekarang ya game seperti itu sebenarnya sangat berpengaruh sekali pada anak-anak terutama karakter. Tokoh-tokoh karakter itu benarbenar merasuk dalam diri anak itu. Kalau saya strategi untuk ke anakanak ya karakternya tokoh itu saya belokkan. Misal Bobo Boy, Bobo Boy ya tetap mau shalat, dia juga rajin shalat, meskipun kalau dilihat dengan film-nya juga sama sekali nggak nyambung.

Peneliti : Kalau orang tua yang aktif dan tidak aktif umi, terlihat nggak sih dari karakter anak mereka? Missal ada orang tua ketika diundang untuk pelatihan, parenting, untuk mengingatkan nilai-nilai karakter juga tidak datang. Apakah ada perbedaan karakter anak-anak yang orang tuanya aktif mengikuti kegiatan sekolah dan tidak?

Umi Yani : Ada yang aktif, tapi anaknya karakternya belum tercapai dengan baik juga ada. Kadang orang tua hanya ikut sekali, tetapi memang pola pengasuhannya di rumah juga balik lagi seperti yang kemarin, jadi 
mungkin di rumah itu kan anak satu-satunya, apa-apa dituruti, jadi egoisnya masih tinggi, di sekolah juga terlihat masih seperti itu. Meskipun orang tuanya ini terlihat ikut aktif parenting. Jadi tidak bisa jadi acuan ya yang aktif atau nggak. Yang jelas masing-masing orang tua punya pola pengasuhan sendiri-sendiri yang kadang susah kita rubah karena memang seperti anaknya yang cuma satu, yang tidak mementingkan karakter jadinya seperti itu, kita susah mengontur.

Peneliti : Yang jelas pasti orang tua ini mendapatkan informasi yang sama ya umi melalui catatan setiap semester atau hari atau berapa kali dalam sebulan itu ada laporan buat orang tua terkait dengan karakter anakanak mereka.

Umi Yani : Iya.

Peneliti : Itu saja umi. Terima kasih banyak atas informasinya.

Umi Yani : Iya. Sama-sama.

\section{Umi Beti (guru sentra memasak)}

\section{Maret 2017}

Peneliti : Mohon maaf umi, saya minta waktunya sebentar. Saya ingin mewawancarai umi terkait denga tema tesis saya "Penanaman nilainilai karakter anak usia dini dengan pendekatan LVE”. Umi sudah cukup lama ya kenal LVE?

Umi Beti : Ya, baru 2 tahun.

Peneliti : Oh umi baru 2 tahun di sini?

Umi Beti : Iya, baru 2 tahun.

Peneliti : Saya berbicara dengan umi siapa niki?

Umi Beti : Umi Beti. 
Peneliti : Umi Beti posisinya sebagai apa di sini? Pengajar saja atau ada tugas yang lain?

Umi Beti : Guru kelas, guru sentra, dan bagian inventaris.

Peneliti : Khusus di sentra memasak ya umi?

Umi Beti : Iya, khusus sentra memasak.

Peneliti $\quad$ : Kalau di sentra memasak ini ada anak-anak RA B juga nggak umi?

Umi Beti : Ada RA B.

Peneliti : Dalam seminggu biasanya berapa kali mereka di sentra memasak?

Umi Beti : Untuk RA B ada 3 kelas, jadi 3 kali pertemuan dalam seminggu.

Peneliti : Ini saya ada beberapa pertanyaan tentang penelitian saya. Pertama, saya ingin tau pendapat umi apa sih pendidikan karakter itu umi?

Umi Beti : Pendidikan karakter kalau menurut saya lebih ke pembiasaan seharihari. Jadi kita terapkan ke anak-anak pembiasaan yang baik seharihari. Yang diajarkan di sekolah nanti bisa diterapkan di rumah juga.

Peneliti : Contohnya seperti apa penanaman nilai-nilai kebaikan kepada anakanak?

Umi Beti : Contohnya kalau bulan ini kan nilainya "baik dan rendah hati", itu ada saling meminta maaf dan memaafkan. Jadi misalkan ada anak yang memang berbuat salah walaupun disengaja atau tidak, kita ajarkan untuk saling memaafkna, meminta maaf. Kemudian juga yang paling sering ni antri, antri minum, antri cuci tangan, kemudian bisa juga menghargai. Untuk menghargai, kadang anak-anak kan masih suka ngece-ngece, menghasut yang jelek-jelek. Kita ajarkan untuk menghargai hasil karya walaupun mungkin belum bagus, kita tetap menghargai.

Peneliti : Kalau yang umi lihat selama ini apakah anak-anak sudah secara sadar meminta maaf kepada teman-temannya atau perlu diberitahu dulu?

Umi Beti : Beda-beda. Ada yang kalau salah langsung minta maaf, ada yang harus dibujuk, ada yang sudah memberitahu temannya, atau ada juga 
anak yang sulit meminta maaf atau mengungkapkan terima kasih. Jadi tergantung masing-masing anak.

Peneliti : Apakah pendidikan karakter di sekolah ini sudah dimuat dalam kurikulum? Misalkan di RPPH, RPPS, atau di rapor siswa.

Umi Beti : Iya, sudah. Untuk kita setiap bulannya ada satu karakter yang kita tanamkan dan untuk karakter lainpun tetap terus kita ingatkan, pembiasaan terus. Misalnya bulan ini kita menghargai, bulan kemarin kerja sama, kita selalu mengingatkan itu. Untuk di RPPH pun sudah ada kegiatan antri minum, antri cuci tangan, dan shalat itu semuanya menerapkan nilai-nilai itu juga.

Peneliti : Umi sudah sejak kapan mengenal LVE?

Umi Beti : Kalau mengenal itu memang baru dua tahun ketika di sini karena sekolah ini menerapkan LVE. Untuk penilaian rapor pun kita ada catatan khusus yang merupakan rekomendasi nilai-nilai yang harus diperhatikan anaknya.

Peneliti : Umi sudah mengikuti berapa kali pelatihan dari Pak Muqowim?

Umi Beti : Kalo pelatihan Pak Muqowim kebetulan yang kemarin nggak ikut. Berarti baru sekitar satu atau dua kali. Saya juga lupa. Hehehe...

Peneliti : Setelah mengikuti pelatihan itu, apa yang mengena di hatinya umi? Apa yang membedakan pelatihan LVE dengan yang lain? Menarik nggak sih pelatihan LVE itu untuk menanamkan nilai-nilai karakter?

Umi Beti : Menurut saya sangat menarik karena kadang-kadang apa yang kita lakukan sehari-hari itu ternyata oh ini salah, ternyata ita nggak boleh, seperti "menghargai" kadang kita sendiri itu belum bisa menghargai diri sendiri. Jadi ketika ikut pelatihan, oh ternyata yang benar ini, dan bisa diterapkan di sekolah ke anak-anak juga. Dalam pelatihan itu kita juga langsung mempraktekkan nilai-nilai itu, tidak hanya diberitau ini nilai "menghargai", tetapi kita langsung disuruh untuk menghargai orang lain melalui aktivitas-aktivitas ketika pelatihan. 
Peneliti : Kalau dalam kegiatan belajar mengajar (KBM), seperti apa sih cara umi memanamkan nilai-nilai karakter pada anak?

Umi Beti : Biasanya kalau begitu secara langsung ya kita misal ketika mau cuci tangan kita himbau untuk antri cuci tangan. Jika ada yang menyela kita ingatkan aturannya tadi apa? "kita harus antri, harus bersabar". Misal ada yang berbuat salah juga kita ngasi tau kalau salah harus minta maaf. Berkali-kali kita ingatkan, ingatkan seperti itu.

Peneliti : Seingat umi sudah berapa banyak nilai karakter yang sudah ditanamkan pada anak-anak?

Umi Beti : Untuk itu banyak ya. Memang kita dalam satu semester itu kita fokus satu bulan satu nilai, tapi nilai yang lain juga tetap dilaksanakan. Kalau yang lalu kita cuma diberitau nilainya ini ini ini, nanti kita pengulangan gitu. Dalam rapor juga seperti itu.

Peneliti : Apa perbedaan sikap/karakter anak yang umi lihat selama dua tahun di sini setelah penerapan LVE? Mempraktekkan, memberikan contoh kepada anak-anak.

Umi Beti : Perubahannya mungkin anak lebih teratur ya. Kalau awal-awal masuk, kebetulan saya kan megangnya kelompok bermain. Dari awal masuk itu biasanya disuruh duduk diam aja nggak bisa. Kadang jalan-jalan. Ketika saya berbicara, anaknya ngobrol sendiri. Habis itu kita kasi pengertian "harus menghargai orang yang sedang berbicara, harus menghargai orang yang lebih tua, harus menghargai temannya", biasanya lama lama anak-anak akan teratur sendiri. Ketika berdoa, kumpul bareng, nggak harus teriak-teriak “ayo...ayoo...kumpul...kumpul”. Untuk awal biasanya memang belum teratur, jadi masih pada ngobrol sendiri, ada yang lari-lari. Selanjutnya sudah bisa lebih teratur.

Peneliti : Untuk mensukseskan program pendidikan karakter ini kan tidak mungkin umi dan teman-teman di sini melakukannya sendiri. Harus 
ada keikutsertaan orang tua juga karena anak-anak justru lebih banyak menghabiskan waktu bersama orang tua. Sukses atau tidaknya pendidikan karakter ini sangat ditentukan juga oleh kesadaran orang tua dalam menanamkan nilai-nilai karakter ini. Apa yang dilakukan oleh sekolah atau yang pernah umi lakukan untuk menggandeng orang tua agar ikut terlibat dalam mensukseskan kegiatan-kegitan/program sekolah?

Umi Beti : Kalau itu sudah semua ya. Kalau parenting memang sebulan sekali mengadakan parenting dan temanya ganti-ganti. Untuk rapor juga kita dibagian akhir biasanya nilai yang diterapkan ketika anak misal anak itu "agak sering berontak" nilai yang cocok buat dia itu apa kita tuliskan di rapor. Kemudian pada saat mengantar dan menjemput, kalau pagi ada yang piket pagi biasanya kalau kemarin ada kejadian khusus, wali kelas biasanya sudah kaya menghadang orang tua untuk memberitahu orang tua terkait kejadian yang terjadi pada anaknya. Misalnya anak ibu kemarin banting kursi. Semuanya kita kasi tau orang tua. Nanti biasanya kita sampaikan kepada orang tua bahwa kita butuh kerja sama orang tua agar anak tidak mengulangi lagi. Kalau untuk di rapor kita memang kejadian atau nilai-nilai juga udah dituliskan.

Peneliti : Apakah ada evaluasi setelah itu? Tidak hanya memberitau orang tua, tetapi setelah itu ada evaluasi atau menanyakan kembali seperti apakah orang tua sudah melakukan seperti yang umi-umi perintahkan dan apakah si anak ada perubahan setelah ada perlakuan dari orang tua.

Umi Beti : Biasanya kadang ada anak "agak bermasalah", kita mesti nanya "kalau di rumah seperti apa ya bu?" Apakah dia juga berantakin alatalat di rumah, kita juga butuh kerja sama dengan orang tua seperti itu. Kalau di sekolah seperti...ini seperti ini, kalau di rumah bagaimana. 
Trus, kalau untuk mengatasi ini di rumah biasanya bagaimana, kita mesti kerja sama ke orang tua.

Peneliti : Kendala apa saja sih yang umi dan teman-teman di sini hadapi terkait dengan penanaman nilai-nilai karakter? Apakah datang dari internal sekolah atau orang tua atau masyarakat, dll?

Umi Beti : Kalau saya memang kebanyakan kadang kita sudah menerapkan di sekolah begini... begini, tapi di rumah belum tentu. Misal kaya yang paling simple saja kaya minum sambil duduk, di rumah "nggak apaapa, papa mama nggak ngelarang", "nggak apa-apa ngerebut mainan, di rumah nggak dilarang”. Kadang-kadang seperti itu. Jadi di sekolah sudah ada aturan seperti ini, tapi di rumah kaya pembiaran gitu. Apalagi di sini banyak yang orang tua sibuk bekerja, jadi ada yang fullday, yang di rumah yang penting anteng atau gimana. Kita sudah wanti-wanti aturannya seperti ini kadang di rumah belum tentu.

Peneliti : Tapi hal-hal semacam itu tetap dikomunikasikan ke orang tua ya umi?

Umi Beti : Iya, kita tetap komunikasikan dan kadang kita paham juga. Oh iya memang orang tuanya sibuk, cuma di rumah sama mbak-nya kaya gitu. Kita kadang-kadang ya maklum.

Peneliti : Banyak menerima laporan juga nggak umi dari orang tua atau masyarakat kalau anak ini bagus banget karakternya?

Umi Beti : Kita memang menggali informasi dari luar/orang tua anak itu seperti apa. Kan kalau pertama masuk pun kita mesti nanya ini karakternya seperti apa. Misal kalau nangis ini lama nggak ya, kalau nangis seperti apa, itu kita mesti nanya ke orang tua, nanya ke lingkungannya ini seperti apa. Jadi kita biar tau nangani anak ini seperti apa. Dan setiap anak beda-beda. Ada yang dikasi tahu sekali sudah bisa, ada yang berkali-kalipun belum tentu bisa karena memang setiap anak beda-beda. 
Peneliti : Umi sendiri tetap sabar ya, tidak menggunakan cara-cara kekerasan dalam menghadapi anak dengan berbagai karakter?

Um Beti : Iya, kita memang dilarang mencubit atau menggunakan kekerasan. Mungkin ada sesekali menggunakan nada yang agak tinggi kalau memang dibutuhkan, tapi kita nggak lah kalau tangan jangan sampai maju. Kita lebih senang menggunakan bahasa yang positif, pendidikan tanpa kekerasan pernah juga dilatih oleh pak Muqowim kalau nggak salah. Jangan menggunakan kata "jangan”. Jadi kalau misalkan anak lari, jangan bilang "jangan lari” tapi "jalan pelan” atau “jangan nakal" kita bilang "sayangi temanmu". Biasanya anak lebih efektif seperti itu dan memang benar ketika anak-anak lari-lari gitu trus kita bilang "jangan lari” wah udah pasti lari. Tapi kalau kita bilang "teman-teman jalan pelan" malah lebih bagus untuk melarang mereka berlari. Kadang-kadang "jangan” itu malah bikin mereka tambah.

Peneliti : Apalagi kalau di pukul ya umi. Hehehe...

Umi Beti : Wah lebih-lebih kalau dipukul. Mereka ta'atnya karena takut, bukan karena mengerti manfaatnya.

Peneliti : Itu saja umi. Terima kasih banyak nggih.

Umi Beti : Iya mas. Sama-sama.

\section{Umi Sesil (guru sentra bahan alam)}

\section{Maret 2017}

Peneliti : Maaf saya ganggu waktunya sebentar umi. Tema penelitian saya ini "Penanaman nilai-nila karakter dengan pendekatan LVE" Ini dengan umi siapa?

Umi sesil : Saya umi Sesil.

Peneliti : Kalau di sini sebagai apa jabatannya? 
Umi Sesil : Guru sentra bahan alam dan juga sebagai humas.

Peneliti : Saya ingin tau, menurut umi apa sih pendidikan karakter itu umi?

Umi Sesil : Menurut saya, pendidikan karakter itu pendidikan yang di mana dalam mendidik anak itu ditanamkan nilai-nilai moral, mungkin lebih ke nilai-nilai positif, seperti kerja sama, menghargai, berbagi, kasih sayang, dan nilai positif yang lainnya.

Peneliti : Pendidikan karakter sendiri menurut umi penting apa nggak?

Umi Sesil : Menurut saya pendidikan karakter itu sangat penting karena untuk pendidikan anak usia dini itu memang harus ditanamkan ke anakanak sejak usia dini. Sehingga nanti akan mengendap sejak kecil, sehingga nanti kedepannya akan memiliki anak-anak yang berkarakter dan juga berakhlaq mulia.

Peneliti : Kalau di sekolah ini tetap mengajarkan baca tulis, atau hanya fokus pada penanaman nilai-nilai karakter saja?

Umi Sesil : Di sekolah ini, kami tidak fokus pada pengajaran baca tulis, tapi kami di sini menstimulus untuk persiapan keaksaraan anak-anak sejak dini.

Peneliti : Caranya melalui apa umi?

Umi Sesil : Tahapannya mungkin untuk tahapan usia RA A kita kasi latihan seperti meniru huruf, seperti itu. Tapi meniru itupun semampu anak, jadi tidak kami paksa meniru sesuai hurufnya. Jadi, sesuai kemampuan anak. Untuk RA B sendiri sudah kami biasakan menulis seperti namanya sendiri atau menulis nama gambar, seperti "rumah", tapi itu juga dengan bimbingan guru. Jadi tidak dipaksakan anak harus bisa menulis sendiri, hanya dikasi rangsangan-rangsangan kegitan selama di sentra.

Peneliti : Kalau konsep pendidikan karakter di RA Tiara Chandra ini seperti apa umi? Apakah penanaman karakter itu sudah melalui pembelajaran secara khusus, dicantumkan dalam kurikulum, RPPH, dll? atau sebatas memberikan contoh dalam kegiatan sehari-hari? 
Umi Sesil : Untuk nilai karakter sendiri untuk di kurikulum pasti sudah ada karena memang kita integrasikan dengan pendidikan karakter sejak awal di sekolah ini. Lalu, untuk konsepnya sendiri, kita setiap hari itu yang terpenting guru sebagai teladan. Dari gurunya dulu harus memberikan keteladanan tentang nilai-nilai pendidikan karakter dari sikap, dari segi bicara, dan juga kita melatih ke anak-anak untuk melakukan nilai-nilai karakter tersebut di setiap kegiatan baik di dalam sentra maupun di luar sentra.

Peneliti : Contohnya seperti apa kegiatan-kegiatan yang berhubungan dengan penanaman nilai-nilai karakter?

Umi Sesil : Contohnya mungkin terutama dalam kegiatan sentra ya. Biasanya ada nilai karakter yang kita fokuskan pada hari itu misalnya "rasa kasih sayang", jadi selama di kegiatan sentra kita menekankan arti kasih sayang itu dan kita ingatkan terus bahwa kita harus menyayangi teman karena setiap kelas itu pasti ada anak yang bersinggungan entah saling dorong, nggak sengaja menginjak, nah itu akan kita tanamkan bahwa kita harus selalu kasih sayang terhadap teman, terhadap semua ciptaan Allah. Jadi kita lebih tekankan terus di dalam kegiatan sentra.

Peneliti : Sejak kapan umi sendiri mengenal LVE?

Umi Sesil : Sebentar. Sejak kapan ya? Hehehehehe....agak lupa tahunnya, yang pasti ini sudah tiga atau empat tahunan, ya sekitar 2012 atau 2013 saya pertama kali mengenal LVE ketika dapat pelatihan di kementerian agama Kota Yogyakarta. Dari situ saya melihat kok ini bagus LVE ini. Saya kira hanya sekedar pelatihan seperti biasa pada umumnya. Tapi kok ternyata bagus dan mengena secara pribadi pada diri saya lalu saya bercerita kepada ibu kepala sekolah, lalu ibu kepala sekolah punya keinginan dan meminta beliau Pak Muqowim untuk mengisi LVE untuk umi-umi di sekolah. 
Peneliti : Kenapa tertarik dengan LVE ini umi? Apa yang membedakan dengan program-program pelatihan atau pendidikan karakter yang lain?

Umi Sesil : Kenapa saya tertarik lebih ke LVE? Karena LVE menurut saya ini beda dengan pelatihan-pelatihan yang lain dan juga LVE ini lebih mengena ke diri pribadi. Dan LVE ini kita lebih banyak untuk prakteknya dibanding hanya mendengarkan dari pembicaranya atau narasumbernya. Sehingga LVE ini bisa langsung dipraktekkan dengan mudah saat itu juga, saat pelatihan.

Peneliti : Sudah berapa kali umi mengikuti kegiatan pelatihan LVE?

Umi Sesil : Saya rasa depalan sampai sepuluh kali ada, tapi saya lupa tepatnya, antara itu delapan sampai sepuluh pernah bersama Pak Muqowim.

Peneliti : Semenjak sekolah ini menggunakan pendekatan LVE untuk menanamkan nilai-nilai karakter pada anak, apakah Pak Muqowim sebagai trainer tetap memantau perkembagan di sini?

Umi Sesil : Iya. Pak Muqowim sangat bertanggung jawab dan juga mendampingi kita sampai saat ini semenjak awal di RA Tiara Chandra ini menerapkan LVE.

Peneliti : Kemudian kalau dalam kegiatan belajar mengajar, bagaimana penerapan LVE ini umi?

Umi Sesil : Dalam kegiatan belajar mengajar, kita selalu salah satunya di awal kita ada pijakan sebelum sentra. Di situ kita berikan nilai-nilai karakternya ke anak, sehingga pada saat kegiatan sentra ketika ada kegiatan yang melenceng dari nilai karakter, maka umi-nya tidak akan pernah bosan untuk selalu mengingatkan bahwa kita harus selalu sayang sama teman, menghargai teman, saling berbagi sama teman. Jadi, di situ kesempatan guru untuk selalu mengingatkan kepada anak-anak.

Peneliti : Seingat umi sudah berapa nilai yang diajarkan pada anak-anak? 
Umi Sesil : Untuk secara tertulis itu baru ada sekitar sepuluh nilai, tapi yang pasti setiap hari kita berikan banyak nilai kepada anak-anak yang menurut saya mungkin tidak terhitung karena anak-anak sejak awal datang ke sekolah sampai pulang pasti anak-anak itu selalu butuh bimbingan dan juga selalu ada nasehat-nasehat dari umi, jadi sudah banyak nilai yang kita terapkan kepada anak-anak dari awal datang sampai pulang sekolah.

Peneliti : Kalau sepuluh nilai itu apa saja umi?

Umi Sesil : Sepuluh nilai itu saya tidak begitu hafal, ada di kurikulum. Tapi yang pasti ada menghargai, rendah hati, kasih sayang, bersikap baik, dan yang lainnya mohon maaf saya tidak hafal, nanti bisa dilihat di kurikulumnya.

Peneliti : Kan umi sudah cukup lama di sini, apa yang kemudian umi lihat perbedaan karakter anak yang dulu dan sekarang setelah adanya LVE ini?

Umi Sesil : Yang pasti sangat terlihat bedanya. Anak-anak bisa lebih mengontrol dari segi sikap dan lisan. Walaupun pasti akan ada anak-anak yang tidak bisa mengntrol diri tapi dengan adanya nilai karakter ini anakanak terlihat bisa lebih menahan dan juga bisa mengendalikan sikapsikapnya di kegiatan di sekolah.

Peneliti : Bagaimana peran dari guru dalam menggandeng orang tua untuk mensukseskan program pendidikan karakter ini?

Umi Sesil : Salah satu caranya adalah pada saat parenting, kami memberikan selembar kertas di mana di situ tertulis perilaku atau kebiasaan anak hebat. Nah, perilaku di situ sudah tertanamkan nilai-nilai karakter tersebut. Dan juga ada salah satu event namanya flea market, baksos, dalam rangka milad sekolah, di situ orang tua biasa diajak kerja sama untuk ikut mengadakan bazar tapi temanya nilai-nilai karakter, ada yel-yel karakter juga. Orang tua jadi tau apa nilai-nilai yang 
diterapkan di sekolah sehingga bisa mendampingi anak-anaknya di rumah juga.

Peneliti : Kalau parenting berapa kali dalam setahun umi?

Umi Sesil : Parenting itu setahun sekitar 4-5 kali. Tergantung nanti tanggalnya tidak tentu, tergantung situasi dan kondisi.

Peneliti : Kegiatan parenting kan tidak bisa diikuti oleh semua orang tua ya karena berbagai macam kesibukan. Cara menggandeng orang tua yang tidak datang pada kegiatan parenting itu seperti apa agar apa yang disampaikan ketika kegiatan parenting juga diketahui oleh orang tua yang tidak datang?

Umi Sesil : Lembaran kertas kebiasaan anak hebat itu yang belum didapatkan oleh orang tua itu akan dibagikan saat orang tua mengantar anak ke sekolah salah satunya. Lalu yang ke dua juga di dalam rapor itu ada nilai-nilai karakter yang kita tanamkan ke anak juga pesan karakter ke orang tua. Jadi orang tua bisa mengaplikasikan nilai karakternya itu tadi ke anaknya di rumah.

Peneliti : Setelah melakukan kegiatan-kegitan menggandeng orang tua itu apakah ada evaluasi setelah itu?

Umi Sesil : Selama parenting pasti saat membagikan lembaran yang berisi kebiasaan anak hebat itu, ibu kepala sekolah akan menanyakan "bagaimana ma/yah kemarin tentang kebiasaan anak hebat itu apakah sudah dilakukan, apa kendalanya" dan orang tua juga berbagi cerita tentang tentang kebiasaan-kebiasaan anak hebat tersebut. Jadi, di situlah evaluasi untuk perilaku nilai-nilai karakter yang ditanamkan oleh orang tua di rumah.

Peneliti : Selain mengikuti pelatihan LVE, umi sudah berapa banyak mengikuti pelatihan lain yang berkaitan dengan pendidikan karakter?

Umi Sesil : Pelatihan pendidikan karakter selain LVE tidak banyak, hanya sekitar satu atau dua saja. Tapi saya lupa judulnya apa, tentang apa. 
Peneliti : Menurut umi LVE lebih baik ya daripada itu?

Umi Sesil : Iya. Kalau menurut saya pribadi seperti itu karena sejak awal udah langsung jatuh cinta pada LVE. Jadi menurut saya LVE ini adalah yang terbaik selama saya mengikuti pelatihan-pelatihan di luar sana selain LVE.

Peneliti : Kita pasti selalu menginginkan yang terbaik buat anak-anak, tetapi ada saja kendala atau ada saja anak-anak yang tidak sesuai dengan harapan kita. Kendala-kendala apa saja sih yang dihadapi selama ini dalam penanaman nilai-nilai karakter pada anak?

Umi Sesil : Yang pasti kendala utama datang dari keluarga karena anak itu kan berawal dari keluarga. Pendidikan pertama sebenarnya adalah keluarga atau lingkungan di tempat anak tersebut. Yang pasti kendala awal adalah dari awal anak itu mendapatkan pendidikan keluarga atau dari lingkungannya di rumah karena sering juga pendidikan yang ada di rumah itu tidak sesuai dengan yang ada di sekolah. Kadan uminya di sekolah sudah menerapkan nilai LVE seperti ini, tetapi di rumah tidak konsisten dalam menerapkannya.

Peneliti : Kalau umi di luar sekolah apakah ikut atau menerapkan nilai-nilai LVE juga?

Umi Sesil : Semenjak ada LVE ini saya mencoba menerapkan ke diri saya sendiri dulu dan alhamdulillah bisa mengendalikannya dengan nilai-nilai tersebut. Lalu saya berusaha belajar menjadi teladan dengan menerapkan nilai-nilai karakter tersebut. Selain itu juga saya kebetulan ada komunitas pengajar. Di situ saya pernah membuat acara, di mana di situ temanya adalah "kerja sama" sesama pengajar dalam acara sekedar bertemu sih silaturrahim, berkumpul, tapi di situ terasa sekali kerja samanya karena di situ kita bersama-sama untuk ada yang membuat sajian, ada yang membuat roti bakar, ada yang di 
sana mengoleskan menteganya, dan di situ kami bersama-sama untuk bekerja sama untuk mempererat tali persaudaraan.

Peneliti : Cukup ya umi. Terima kasih banyak.

Umi Sesil : Iya mas. Sama-sama.

\section{Umi Yuni (guru Sentra Main Peran) 25 Maret 2017}

Peneliti : Maaf umi, mengganggu. Saya ingin wawancara sedikit terkait dengan teman penelitian saya yaitu "Penanaman nilai-nilai karakter untuk anak usia dini dengan pendikatan LVE". Kalau umi sudah berapa tahun di sini?

Umi Yuni : Saya sejak tahun 2007. Berarti sudah hampir 10 tahun.

Peneliti : Sekolah ini berdirinya tahun berapa umi?

Umi Yuni : Tahun 2002.

Peneliti : Namanya siapa njenengan?

Umi Yuni : Saya umi Yuni aja.

Peneliti : Saya ingin tau umi apa sih pendidikan karakter itu umi?

Umi Yuni : Pendidikan karakter itu ya seperti penerapan norma. Sebenarnya sudah ada ya di indikator anak-anak sebelum ada LVE pun sudah ada.

Peneliti : Menurut umi, pendidikan karakter itu penting nggak sih?

Umi Yuni : Penting sekali, sangat penting ya.

Peneliti : Apakah konsep pendidikan karakter itu sudah dimuat dalam kurikulum?

Umi Yuni : Kalau yang di rapor itu sudah dari tahun ajaran yang kemarin, tapi untuk yang di penerapan di kurikulum itu baru semester ini, masuk ke RPPH juga semester ini. Walaupun sebelumnya sih sudah, tapi mungkin belum masuk ke RPPH. 
Peneliti : Bentuknya seperti apa kalau yang di rapor?

Umi Yuni : Kalau yang di rapor itu misalkan anak ini cenderungnya apa. Misalnya anak itu suka berantem, nanti kita ngasi nilainya "damai". Damai itu apa apa apa, kita ambil dari LVEnya itu. Apa yang harus diterapkan untuk anak itu juga di rumah.

Peneliti : Sudah berapa lama umi mengenal LVE?

Umi Yuni : Saya sejak di Jogokaryan itu sudah 3 tahunan lah. Kegiatan-kegitan pelatihan di sekolah dan kemenag yang disampaikan pak Muqowim saya sudah ikut. Kita pokoknya setiap semester 2 mengadakan pelatihan.

Peneliti : Menurut umi, apa yang membedakan LVE dengan yang lain?

Umi Yuni : Kalau LVE itu bisa langsung dipraktekkan. Lebih interaktif. Kalau di ESQ itu karena pesertanya banyak banget, jadi seperti mendengarkan aja. Kalau di LVE ini mau mengungkapkan apa, mau bercerita apa juga boleh.

Peneliti : Kalau penerapan LVE dalam kegiatan belajar mengajar seperti apa umi?

Umi Yuni : Biasanya di RPPH itu sudah ada ya. Hari ini, tema ini. Tapi tanpa harus seperti itupun tetap bisa dimasukkan setiap hari ya. Banyak sih, nggak harus yang ini. Kalau memang sekarang harus dimunculkan ini ketika kejadian apa, itu sudah LVE menurut saya. Walaupun di RPPH sudah dicoba mencantumkan nilai tertentu, tetapi pada saat ke kelas itu banyak nilai yang kita hidupkan. Misalkan hari ini "menghargai" padahal mungkin yang muncul bukan itu pas anakanak di kegiatan sentra. Sebenarnya nilai karakter nggak bisa di teori ya mas Amar, jadi malah langsung praktek.

Peneliti : Mungkin itu hanya untuk administrasi saja, tapi pada saat kegiatan akan banyak sekali nilai yang muncul. 
Umi Yuni : Iya, banyak banget. Munculnya nggak mesti yang kita masukkan di RPPH. Mungkin di RPPH cuma satu nilai, padahal yang muncul banyak sekali.

Peneliti : Kalau yang pernah saya dengar setiap upacara hari Senin itu kan ada nilai yang dimunculkan. Misalkan hari ini nilai kita "menghargai". Itu biasanya nilainya diganti dalam waktu berapa lama umi?

Umi Yuni : Satu tema itu ya tujuh kali putaran. Berarti sekitar satu minggu lebih sedikit. Setiap tema berubah, maka nilai juga berubah, tetapi nilai yang lama tetap juga dihidupkan.

Peneliti : Selama penerapan LVE ini sudah berapa nilai yang dihidupkan?

Umi Yuni : Kayaknya hampir semua deh. Mungkin yang kaya nilai persatuan untuk anak-anak TK seperti kerja kelompok gitu. Dalam satu kegiatan itu sudah bisa masuk beberapa nilai.

Peneliti : Menurut umi, bagaimana perbedaan antara sebelum dan sesudah mengikuti pelatihan LVE? Entah dari sisi umi sendiri yang mengikuti pelatihan, atau dari sisi anak-anak yang melihat dan merasakan perubahan karakter umi.

Umi Yuni : Kalau saya paling ternyata nilai karakter itu banyak ya. Jadi bukan cuma buat kita pribadi, tapi juga buat anak-anak penting. Anak-anak perlu ditanamkan juga dari kecil.

Peneliti : Anak-anak ada perubahan nggak setelah umi-umi sudah mulai sadar nilai?

Umi Yuni : Ada. Walaupun masih berulang juga mungkin ya. Misalnya kaya sukanya memukul, kalau sama teman itu harus kasih sayang, sayang orang tua. Atau mungkin kalau menghargai, menghargai itu seperti apa. Atau yang masih sering anak-anak itu mereka masih suka ngece gitu. Hal itu yang masih harus kita beritahu terus. Kalau yang lainnya sih setiap hari kita kasi tahu. Misalkan "damai" itu nggak mukul, nggak nendang, nggak nyubit, seperti itu aja. 
Peneliti : Anak-anak terlihat nggak ada perubahannya?

Umi Yuni : Ada. Misalkan kata umi haru begini-begini, seperti itu. Dan kita tetap harus terus diberitahu. Namanya anak kecil ya nggak bisa langsung bim salabim.

Peneliti : Pengalaman umi sendiri, bagaimana cara umi melibatkan orang tua dalam pendidikan karakter anak?

Umi Yuni : Biasanya kita sih, misalkan ada sesuatu yang harus di ini dari anak, kita biasanya langsung sampaikan ke orang tua biar nanti di rumah juga seperti itu, sama seperti yang mau kita berikan ke anak di sekolah. Ada juga kegiatan flea market dan pelatihan LVE yang melibatkan orang tua. Walaupun belum semuanya karena ada yang sibuk.

\section{Umi Ratna (kepala sekolah)}

\section{Maret 2017}

Peneliti : Saya ingin mengetahui bagaimana peran kepala sekolah dalam memastikan semua kegiatan belajar mengajar, memastikan umi-umi disini itu sesuai dengan yang diinginkan kepala sekolah. Yang pertama umi saya ingin tahu dulu seperti apa sih, apa sih yang dimaksud dengan pendidikan karakter menurut umi sendiri?

Umi Ratna : Pendidikan karakter kalau menurut saya, menurut teman-teman disini adalah bagaimana kita membiasakan hal-hal positif yang bisa membangun karakter, tentunya karakter positif anak seperti itu. Jadi karena untuk membangun karakter tidak cukup waktu sebulan, dua bulan, tetapi dia memerlukan jangka yang panjang berbeda dengan kemampuan akademis ya. Kalau kemampuan akademis, umi-umi berani ditantang untuk bisa memberikan satu materi dalam satu bulan misalnya, karena Insya Allah anak-anak itu cerdas banget, diajarin 
apa aja bisa masuk. Tapi kalau karakter itu kita butuh proses. Prosesnya juga tergantung, tidak hanya bergantung dari anak tetapi tergantung dari kita yang ada di lingkungan anak keseharian, bisa sekolah bisa rumah bisa masyarakat seperti itu. Jadi untuk anak usia dini kami memiliki kepahaman yang sama. Umi-umi umi disini memiliki tujuan yang sama bahwa membentuk karakter anak itu lebih penting ketika saat usia dini dan itu saat-saat yang bagus untuk bisa membangunnya. Jadi akhirnya itu yang membuat kami memutuskan membangun karakter anak melalui penerapan LVE seperti itu.

Peneliti : Kemudian konsep pendidikan karakter di RA Tiara Chandra itu seperti apa sebenarnya, mungkin dalam bentuk implementasinya apakah dituangkan ke dalam kurikulum kemudian itu nanti berupa mungkin proses belajar mengajarnya seperti apa kemudian mungkin rapotnya bagaimana untuk memudahkan koordinasi dengan orangtua?

Umi Ratna : Jadi kalau untuk prosesnya proses untuk kita membangun karakter anak itu pertama memang kita masukkan ke dalam kurikulum kita. Jadi di kurikulum kita, kita masukkan, kemudian setelah terbentuk kurikulum, kurikulum yang berwujud ya dan ada juga hidden kurikulum jadi yang tidak kita tuliskan disitu tetapi kita lakukan dalam hal sikap kita pada saat kita berinteraksi dengan mereka. Kita sebagai role model kita sebagai contoh untuk anak-anak bagaimana kita bisa menjadi sosok-sosok yang memang positif dalam segala hal di mata anak-anak, sehingga anak-anak bisa meniru itu. Jadi kita tuangkan ke dalam kurikulum, kemudian kita laksanakan dalam aktivitas sehari-hari. Tadinya kita stop sampai disitu, itu beberapa tahun yang lalu. Semenjak 7 tahun belakangan ini, kita sudah mulai share kan hal ini ke orangtua karena kalau cuma di sekolah saja ga akan maksimal gitu. Ketika di sekolah, anak-anak bisa seperti tujuan 
pembelajaran yang kita mau, tetapi ketika di rumah ataupun mungkin ketika kegiatan bersama dengan sekolahan tetapi ada orangtuanya ternyata beberapa karakter positif ini bisa hilang. Contoh sepele aja anak-anak terbiasa bertanggungjawab. Bertanggungjawab sampelnya membuang sampah pada tempatnya, tetapi suatu saat ada kegiatan ekstrakurikuler berenang di situ ada orangtua dan saat snack time kita serahkan snack ke anak-anak dan mereka makan dengan orangtua. Ternyata kita lihat beberapa anak tetap bertanggungjawab tetap karakternya sudah jadi gitu ya, dia membuang sampah pada tempatnya. Tetapi, beberapa anak dan lebih banyak dari yang bagus ini ya tidak membuang sampah pada tempatnya itu sampel kecil dan ternyata orangtuanya tidak mengingatkan. Dan dari situlah kita mulai, oh ternyata juga perlu kita rangkul untuk bisa menjadi bagian dari program ini. Jadi sejak dari 2010 kita mulai rangkul mereka untuk bisa memahami tentang program sekolah, tidak hanya kita sosialisasi tetapi kita ajak mereka bersama untuk membiasakan halhal positif yang memang tujuannya untuk menumbuhkan karakter mereka untuk bisa dilakukan juga di rumah gitu. Seperti itu jadi itu kita mulai share kan ke orangtua sosialisasikan kemudian praktek. Prakteknya ya dengan waktu itu kita mebuat kartu anak hebat jadi tujuh kebiasaan anak hebat, kita bagikan ke orangtua "Tolong ya tujuh kebiasaan ini kita lakukan di sekolah, di rumah tolong mama dan papa mengingatkan”, jadi bisa kontinyu seperti itu.

Peneliti : Kemudian kalau mengenal LVE ini sejak kapan, umi?

Umi Ratna : LVE kita kenal 2009, 2010 kita udah mulai meminta Pak Muqowim menjadi pelatih disini.

Peneliti : Kalau ketertarikan untuk menggunakan LVE ini kenapa kok bisa tertarik, apa yang menarik dari LVE ini? 
Umi Ratna : Pertimbangannya banyak sebetulnya, jadi pertimbangannya lebih ketika saya menemui kesulitan untuk mempraktekkan manajemen pengelolaan SDM itu. Sebenarnya saya menemui itu, karena ternyata person-person pendidik tidak hanya pendidik ya, staf juga disini ada kebersihan, ada keamanan itu kan basic pendidikannya macammacam, berasal dari lingkungan yang macam-macam. Ternyata ketika saya mencoba untuk mengajak mereka memahami satu hal secara bersama-sama itu agak kesulitan. Meskipun kita ada yang namanya internal quality forum atau IQF, waktu itu saya sering banget setiap Sabtu, tetapi beda orang beda pemahaman gitu dan tidak sama hasilnya. Saya juga sudah coba untuk mengikutsertakan mereka ESQ. ESQ ada perubahan paling seminggu setelah mengikuti kegiatan dan mereka mulai tersadar mulai memperbaiki diri, tapi ga nyampe dua minggu itu udah balik lagi, jadi sebetulnya dari situ sampe akhirnya kami mengikuti pelatihan yang dilaksanakan Kemenag Kota waktu itu dan saya melihat disini kita tidak diajak menangis-nangis, bersedih-sedih untuk memahami motivasi kita gitu. Kalau “mohon maaf” ESQ, saya berpendapat seperti itu, kita diajak sedih diajak menangis. Memang kita digali untuk bisa lebih memahami apa sih motivasi kita, tapi itu ternyata nggak awet gitu, palingan seminggu saya sadar banget motivasi tapi setelah itu hilang lagi gitu karena kesadarannya itu dimasukkan secara apa ya..... secara lingkungan karena semuanya sedih nangis, kita jadi memahami tapi setelah itu ya kita sudah lupa lagi. Tetapi kalo LVE beda, LVE menurut saya kita tidak harus bersedih, kita tidak harus dipaksa menyadari motivasi kita tetapi justru kita diajak untuk melihat hal-hal kecil yang selama ini kita tidak begitu memperhatikan, hal-hal kecil yang ada di lingkungan kita yang sebetulnya itu motivasi kita apa ya dari situ gitu, dari hal-hal kecil 
yang terbiasa selalu ada di lingkungan kita yang selalu kita lihat membuat saya teringat akan motivasi saya apa gitu tidak harus dengan menggali dengan menangis-nangis kayak gitu ya. Jadi melihat hal-hal yang ada di lingkungan saya, saya selalu melihat apa sih motivasi saya gitu terutama pendidik. Pendidik disini meskipun beda-beda lingkungannya, beda-beda sifat dan wataknya tetapi saya beranggapan ketika mereka sudah mendapatkan sentuhan LVE itu tentunya akan berbeda ketika dia menyentuh anak-anak seperti itu. Kita tidak hanya menjadi guru itu tidak hanya sebuah pekerjaan tetapi itu sebuah tujuan besar sebuah misi besar untuk bisa membawa anak-anak ini menjadi generasi-generasi yag hebat gitu. Tidak harus muluk lah ngajarin mereka bilingual segala macam tidak harus seperti itu, kita ajak mereka untuk bisa menyadari nilai itu, itu aja dulu, nanti semuanya gampang semuanya ngikut apalagi akademis, wah anak-anak itu diajarin apa aja cepet banget, tetapi untuk karakter untuk mereka memahami nilai-nilai universal yang ada di lingkungannya kalau tidak dibiasakan itu sepertinya akan sulit. Sudah diberikan sentuhan itupun kadang-kadang ada masih ya mungkin permasalahan-permasalahan hidup segala macam sehingga kami merasa memang perlu refresh gitu.

Peneliti : Terus sudah berapa kali Umi semenjak menerapkan LVE ini sudah berapa kali semua elemen yang ada di sekolah ini mengikuti pelatihan-pelatihan dari Pak Muqowim?

Umi Ratna : Kalau berapa kalinya ya minimal satu tahun itu dua kali. Kalau kita dari 2010, ya berarti sekitar 14 kali sudah pernah mengikuti. Setidaknya kami agendakan setahun dua kali minimal, kadang pernah juga setahun tiga kali atau ada juga sih yang masih baru guru-guru baru yang memang baru beberapa kali. 
Peneliti : Kalau yang Umi lihat sendiri setelah mengikuti pelatihan-pelatihan dari LVE yang diadakan oleh Pak Muqowim ini, apa perbedaan yang paling signifikan antara karakter guru-guru, kebiasaan selama ini dengan setelah mengikuti pelatihan LVE?

Umi Ratna : Kalau perubahannya banyak ya, meskipun mereka memang sebetulnya sosok-sosok terplilih ya sehingga bisa bergabung dengan kami biasanya. Biasanya kami juga melakukan seleksi, tetapi dengan mengikuti kegiatan LVE itu, mereka tu beda jauh banget. Dilihat aja guru baru ya, guru yang baru mengikuti pelatihan LVE sekali dua kali dengan yang sudah berkali-kali itu dari cara bicaranya kemudian dari sikapnya, dari kebiasaan hari-hariannya itu sudah sangat terlihat. Pertama itu tanggungjawab. Tanggungjawab guru-guru disini terus terang kalau mereka sakit sampai nggak bisa jalan baru mereka nggak masuk. Kenapa? Karena mereka menyadari betul tanggungjawabnya. Ketika saya tidak masuk berarti hari ini saya tidak bisa bersama anak-anak, berarti hari ini saya tidak bisa membagikan hal-hal baik kepada anak-anak, biasanya gitu. Guruguru disini seperti itu, jarang sekali mereka nggak masuk kecuali mereka nggak bisa jalan mereka nggak berangkat, beda dengan guruguru baru. Guru baru ya mungkin mereka nggak pernah mengikuti LVE, itu tu meskipun kita sudah ada MoU ya kesepakatan kerja kalau nggak masuk gini gini gitu tapi kertas itu gaada bandingan apaapanya dengan kesadaran diri. Banyak sih dan kita disini alhamdulillah sama-sama saling menjaga, saling mendukung gitu. Ada satu yang nggak bisa, ya yang lainnya siap.

Peneliti : Berarti kerjasamanya luar biasa kalau saya lihat termasuk sama Bapak Security, wah luar biasa. Saya lihat itu membantu apapun apa yang beliau bisa bantu. 
Umi Ratna : Ya itu memang nuansa kerja yang saya inginkan seperti itu. kita tidak perlu ada batas, seperti saya dengan mereka juga, saya juga tidak ingin mereka membatasi diri gitu. Meskipun disini posisi saya kepala ataupun pemilik tetapi saya sama dengan mereka. Disini kami mempunyai tujuan sama gitu.

Peneliti : Kemudian kalau manusia ini kan suka naik turun Umi ya, termasuk kita termsuk saya juga jadi sebaiknya sebagai kepala sekolah apa sih langkah-langkah yang Umi lakukan untuk memastikan Umi-umi ini ketika datang ke sekolah ini mereka memiliki aura LVE itu, apapun masalah di rumah?

Umi Ratna : Ya, itu jadi kadang yang susah ya. Meskipun kita ada kesepakatan yang tidak kita tulis tetapi kita semua paham. Jadi kita punya satu kesepakatan bahwa ketika kita tidak nyaman, tolong sampaikan ke teman jangan sampai kita tidak nyaman dan kita mengajar hari itu, biasanya gitu. Ada guru yang sering banget "Umi hari ini saya rasa nggak nyaman karena di rumah gini gini gini, saya nggak bisa pegang anak" itu ada itu namanya Umi Nur tapi dia tidak ada disini, dia ada di Godean. Tapi sebetulnya itu satu kesepakatan yang samasama kita miliki dan terkadang ada juga dia ngerasa nggak nyaman tetapi dia merasa bertanggungjawab untuk bisa memegang anak-anak dan biasanya memang hasilnya kurang bagus. Sebetulnya betul banget seperti yang pernah Pak Muqowim ceritakan "kunci dari masakan enak ini apa sih". Disitu yang memasak orangnya bahagia sekali. Nah kita juga kepengen begitu, hari ini anak-anak belajarnya happy banget ya, karena apa, karena uminya juga bahagia. Kita maunya gitu, tetapi kadang-kadang ada juga yang di rumah namanya manusia yang ada permasalahan, mungkin tadi anaknya rewel atau suaminya kenapa itu nggak nyaman. Kalau Umi Nur saya acungkan jempol karena dia selalu terbuka dengan perasaannya. Nanti sejam 
dua jam "Umi saya sudah meraskan lebih nyaman dan saya bisa pegang kelas". Tapi rata-rata kebanyakan yang lain itu lebih menekan diri gitu. Jadi udahlah nanti permaslahan saya dipikirin. Ada juga yang seperti itu, tetapi saya pribadi saya lebih suka "Umi saya ga nyaman hari ini, kayaknya kalau untu pegang kelas saya kurang bisa maksimal, boleh ya Mi kalau saya sudah nyaman”, itu kalau Umi Nur seperti itu. tetapi kalau temen-temen yang lain, mereka lebih ke simpan dulu permasalahan yang tadi nanti kita pikirkan setelah kita selesai belajar dengan anak-anak gitu.

Peneliti : Jadi lebih baik kualitas daripada kuantitas gitu?

Umi Ratna : Iya

Peneliti : Berjam-jam sama Umi yang galau itu kan lebih baik cuma satu jam dengan Umi yang ini?

Umi Ratna : Iya, itu biasanya dengan yang ini kan kalau mungkin saya ketemu "Umi kenapa gitu kan”. Biasanya kalau saya melihat lebih baik "Umi ke depan aja di FO gitu”. Tapi saya jarang sih menemukan gitu, terkadang sudah KBM itu mereka kembali ke tempat aslinya. Tapi gapapa ya namanya manusia, kita ga boleh "kamu harus jadi kayak gini”, yang penting ya ketika dengan anak-anak kita punya satu komitmen yang sama, kita harus mengajar dengan bahagia.

Peneliti : Jadi intinya, ya apapun masalah di rumah berusaha untuk barengbareng?

Umi Ratna : Iya, jadi kesepakatannya gini ketika kita sudah melangkahkan kaki kita memasuki sekolahan ini, kita simpan dulu semua permasalahan yang kita punya, hari ini kita hadir untuk anak-anak seperti itu. Ketika kita sudah merasa tidak nyaman, tolong sampaikan ke teman. Tetapi ketika ada kita melihat teman kita yang ga nyaman, kita saling mengingatkan sebetulnya itu. Jadi satu tata tertib atau satu kesepakatan yang tidak tertulis gitu. Karenakan ga mungkin ya 
menyuruh manusia kok lurus-lurus terus gaada masalah kan ga mungkin. Pasti ada. Jadi salah satu jalannya mungkin sharing dengan teman juga saling mengingatkan, juga mungkin dengan pelatihanpelatihan. Iya, makanya ada refresh, ada pelatihan-pelatihan, ada evaluasi, terutama evaluasi, sepertinya Mas Amar belum pernah ikut ya. Ada evaluasi untuk sikap kita untuk bagaimana perilaku kita pada saat bekerja itu biasanya memang satu semester sekali. Kita saling memberi masukan ke teman. Itu satu semester sekali di akhir tahun ajaran.

Peneliti : Terus selanjutnya bagaimana sih sebenarnya konsep LVE ini dalam keseharian jadi aplikasinya dalam keseharian, contoh seperti saya pernah melihat itu ketika upacara bendera ya Umi, jadi ada satu nilai yang disampaikan oleh Umi. Hari ini nilai kita adalah tanggungjawab misalnya seperti itu. itukan bagian dari konsep LVE sebenarnya ya Umi. Nah selama ini yang sudah dijalankan di sekolah ini seperti apa?

Umi Ratna : Ya, jadi gini kalau kita dalam keseharian sebetulnya ingin menghidupkan nilai-nilai tadi, nilai-nilai apapun yang kebetulan ada di sekitar anak atau bahkan ketika ada kasus yang dialami anak. Disitu, kesempatan kita untuk menghidupkan nilai-nilai edukasi mereka. Akan tetapi selain itu, selain dari perilaku dan sikap keseharian kita memang setiap satu bulan kita mengangkat satu nilai, jadi ada satu nilai yang kita angkat jadi yang kita tonjolkan, seperti mungkin nilai tanggungjawab kemudian tanggung jawab itu apa. Nanti kita breakdown lagi menjadi tujuh prakteknya gitu. Misalnya setiap selesai bermain, aku mengembalikan mainan pada tempatnya. Jadi kan itu prakteknya, dan itu dilakukan di satu kelas. Jadi nanti cara kita adalah satu bulan ini Maret misalnya atau Februari kemarin kita mengangkat nilai tanggungjawab. Nanti kita brainstorming sama 
Umi-uminya, nilai tanggungjawab apa ya Umi yang pengen Umi biasakan ke anak-anak, membereskan mainan sendiri Umi" itu nanti di kelas sentra persiapan misalnya. Kemudian bertanggungjawab dengan misalnya apa lagi ya, ada banyak sih, kemarin brainstorming Umi-Umi sampai kita ketemu tujuh praktek dari menghidupkan nilai tanggungjawab. Membereskan mainan sendiri, merapikan bawaan sendiri seperti itu atau mungkin karena aku seorang siswa aku akan semangat belajar termasuk bertanggungjawab. Jadi beberapa hal itu kita breakdown prakteknya apa dan itu kita tulis, kita print ya, kita tempel di kelas-kelas yang memang misalkan ada anak yang bilang "umi Kiki aku kepengennya di kelasku merapikan mainanku sendiri” ya kita tempel di kelas umi Kiki. Kemudian di kelas umi yang lain beda-beda lagi sesuai dengan brainstorming mereka, dan itu kita publish di facebook. Harapannya orang tua memang tidak kita kasi satu-satu, tapi harapannya mereka bisa print sendiri. Tapi rata-rata mereka print sendiri. Mungkin sample-sample banyak sih, kaya mama Dipo itu setiap kita ada tema baru, kosa kata baru dia pasti print dari facebook dan dia tempelin di rumah termasuk nilai-nilai yang ditonjolkan, digaris bawahi setiap bulannya.

Peneliti : Itu disepakati sama anak-anak juga nggak umi?

Umi Ratna : Iya, iya. Sehingga menghidupkan nilai tanggung jawab, "aku bertanggung jawab, aku membereskan mainanku sendiri" itu dihidupkan betul di satu sentra itu. Meskipun sebenarnya di sentra lain harapannya semua nilai itu dia praktekkan, tidak hanya ketika di sentra persiapan aja.

Peneliti : Selama penerapan LVE ini sudah ada berapa nilai yang ditonjolkan atau yang coba dihidupkan?

Umi Ratna : Banyak sekali. Tanggung jawab, jujur, percaya diri, kerja sama, kasih sayang. Banyak ee mas. Udah banyak sekali. Dan itu sepertinya di 
beberapa anak sudah sangat terlihat. Anak-anak yang sudah memahami tentang menghidupkan nilai itu mereka terlihat sekali dengan mereka kritis, mereka berani berpendapat, mereka pasti tidak akan segan untuk mengingatkan temannya. Seperti itu. kalaupun terjadi kasus berebut, berantem, itu nanti pasti muncul satu yang menjadi penengahnya. Dan itu bukannya kita membiarkan, tetapi kita melihat prosesnya. Nanti kalau memang betul-betul umi perlu untuk turun, baru umi turun. Kita coba anak-anak bisa nggak sih menyelesaikan permasalahan mereka dengan menerapkan nilai-nilai yang sudah kita coba untuk bangun ke mereka.

Peneliti : Berbedaan apa yang paling menonjol ketika sebelum dan sesudah menggunakan LVE?

Umi Ratna : Perbedaannya terlihat banget ketika pertama kami menerapkan LVE untuk internal kami dulu. Jadi internal itu pengelola, guru, dan karyawan. Kemudian setelah itu baru kita praktek ke anak-anak, setelah itu baru kita ke orang tua, setelah ke orang tua, level berikutnya kita ke masyarakat. Kita ingin mengenalkan nilai-nilai. (1) Hal pertama yang saya lihat adalah, saya lebih mudah mengajak tim saya ini untuk berlari. Untuk kita bisa membuat inovasi-inovasi baru, tidak lagi mereka yang “ah aku kan cuma ngajar". Tidak lagi seperti itu. Mereka punya mimpi, gitu. Kalau tadinya kan ngajar tok, tapi sekarang mereka nggak merasa seperti itu. Itu perbedaan pertama yang saya rasakan. (2) Kemudian berikutnya dari anak-anak, dari murid-murid yang memang kita dampingi dengan kita menghidupkan nilai-nilai itu ternyata output nya juga berbeda. Kami berani membandingkan dengan output dari sekolah lain meskipun samasama pendidikan karakter. (3) Kemudian yang berikutnya lagi yang sangat luar biasa adalah orang tua. Kalau dulu orang tua ya hanya sekedar memasrahkan anak-anaknya untuk dididik di sini, sudah, 
yang penting kewajibannya membayar SPP. Parenting dari dulu sudah ada, tapi kan sekedar datang mengikuti materi yang diberikan narasumber yang kita cari. Gitu aja sudah. Tetapi, ketika kami sudah memasukkan LVE ke mereka, ternyata support mereka sudah beda. Jadi, mereka kita ajak untuk bisa menjadi bagian dari tim ini. Jadi kami memberikan pemahaman bahwa anak-anak kalau cuma sekolah aja nggak bakalan maksimal. Tetapi kita butuh kerjasama dengan orang tua dan alhamdulillah orang tua memahami tentang itu. Jadi mereka support banget setiap program yang kita lakukan, seperti kita ajak mereka untuk mensosialisasikan nilai kepada masyarakat itu mereka semangat juga. Dengan kegiatan baksos nilai, kemudian pentas nilai, mereka merasa masyarakat juga perlu tau bahwa sebetulnya nilai itu tidak hanya kita tuliskan, tidak hanya kita sebutkan, tetapi kita lakukan. Ya harapannya sih, dari satu orang tua ini dia mengimbaskan diri ke lingkungannya, setidaknya lingkungannya juga sudah bisa mempraktekkan tentang bagaimana menghidupkan nilai.

Peneliti : Apa saja faktor-faktor penghambat penerapan LVE selama ini umi?

Umi Ratna : Sebetulnya saya rasa nggak ada ya kalau faktor penghambat. Cuma lebih ke person aja yang memang naik turun ya emosinya. Sehingga kita memang perlu refresh. Kemudian dari basic lingkungannya. Ini kita membicarakan tentang orang dewasanya ya. Mungkin dari basic lingkungannya yang memang tidak biasa menghargai orang mungkin ketika berbicara. Mungkin kesulitannya di situ. Ketika kita ingin membiasakan nilai-nilai itu ada, hidup dalam diri kita, tetapi lingkungan di mana mereka tinggal itu tidak mendukung, kadangkadang ya menurun.

Peneliti : Cara umi untuk memastikan orang tua mengikuti seperti program yang dilakukan di sekolah, selain dari parenting, apa lagi umi? 
Umi Ratna : Kita ada kuisioner LVE, pernah. Jadi harapannya orang tua juga nggak asing. Apa sih LVE? Kita ada testimoni. Kita memang ingin melihat bahwa program kita itu sampai di mana. Kuisioner khusus tentang LVE itu misal, apakah perubahannya setelah anak-anak kita dampingi, kita bangun karakternya denga LVE. Itu banya mereka memberi komentar. Termasuk salah satunya kegiatan baksos itu. Jadi mereka tidak hanya tau kasih sayang, tetapi kita suruh bikin yel-yel tentang kasih sayang, dan ketika ada pembeli yang datang, nah itu kesempatan kita untuk share ke masyarakat bahwa nilai-nilai itu ini lo. Termasuk di pementasan-pementasan nilai ketika kelulusan. Itu yang kita undang tidak hanya orang tua, tetapi dari rekan kita sesame profesi guru, dari dinas, dari kemenag. Harapannya mereka juga sadar ternyata nilai tu ini to. Biasanya kita kasi sinopsis, apa sih yang ingin kita angkat di situ agar mereka bisa mengerti. 
